\title{
Wither Sanctuary?
}

\author{
RANDY K. LIPPERT
}

\begin{abstract}
Features of all fifty sanctuary incidents occurring in Canada from 1983 to early 2009 are described and recent trends identified. The duration of sanctuary incidents has increased dramatically, the success rate has declined, and no new incidents have commenced in more than one and a half years. Sanctuary's apparent decline in its "exposure" form as an effective resistance strategy is likely related to several factors, including less interest among mass media, the federal government's adoption of a more authoritarian approach toward immigration and refugee policy, and the rise of support for a merit-based legal appeal for failed refugee claimants evident in sanctuary discourse.
\end{abstract}

\section{Résumé}

Les caractéristiques des cinquante cas de sanctuaire survenus au Canada de 1983 au début 2009 sont décrites et les tendances récentes identifiées. La durée des cas de sanctuaire a augmenté de façon spectaculaire, leur taux de réussite a diminué, et aucune nouvelle demande d'asile n'est survenue depuis plus d'un an et demi. La baisse apparente de l'efficacité du refuge dans sa forme "médiatisée " comme stratégie de résistance est probablement liée à plusieurs facteurs, dont une baisse de d'intérêt parmi les médias de masse, l'adoption par le gouvernement fédéral d'une approche plus autoritaire à l'égard de politiques sur l'immigration et les réfugiés ainsi qu'une augmentation, évidente dans le discours entourant la notion du sanctuaire, de l'appui pour le recours juridique fondé sur le mérite pour les demandeurs d'asile déboutés.

\section{Introduction}

Emerging in the early 1980s across the West, sanctuary has entailed providing protection in church buildings to migrants facing imminent arrest and deportation, often for extended periods, and making migrants' plight known to the public and state authorities. By the early 2000s in Canada, this "exposure" form of sanctuary had become a de facto last court of appeal for some failed refugee claimants facing deportation. Yet, despite its relative success in securing status or reprieves for migrants in peril, more recently this form of sanctuary is showing signs of withering. ${ }^{1}$ One aspect cohering with this development, and revealing both of how sanctuary is changing and its possible future, is the rise of the merit-based appeal as an emergent goal in the discourse of sanctuary providers.

This article has two purposes. First, it seeks to update a comprehensive 2005 study of Canadian sanctuary that explored all thirty-six sanctuary "exposure" incidents from 1983 to $2003 .^{2}$ Another fourteen sanctuary incidents have commenced since and remain unexamined in relation to this earlier study's findings. The aim in the first section of the paper, then, is to provide a brief but up-to-date sketch of twenty-six years of sanctuary in Canada and discern if and how this phenomenon is changing. Thus, I describe basic features and trends of the Canadian sanctuary phenomenon to April 30, 2009. While many features of sanctuary incidents remain largely unchanged after 2003, I argue the sanctuary phenomenon is nonetheless mutating in several ways and most significantly-in its "exposure" form at least-is showing signs of withering away as a resistance strategy. Thus, despite increased awareness of sanctuary as a possible resort and its past success in securing positive legal outcomes, in recent years the duration of sanctuary incidents has increased dramatically; the success rate has noticeably declined from previous levels; and no new incidents have occurred in more than a year and a half. The final part of the article, consistent with these findings, aims to further explore how and why sanctuary is changing. Thus, the second purpose of this article is to consider possible 
reasons for identified trends and their implications for sanctuary's possible future. I argue that sanctuary's apparent decline in its "exposure" form is likely due to several factors, including less interest among mass media and the federal Conservative party's rise to power in 2006, accompanied by a more authoritarian approach to managing immigration and refugee policy than its Liberal government predecessor. However, the rise of support for a merit-based legal appeal for failed refugee claimants in sanctuary discourse is also significant in suggesting where sanctuary might be leading and is therefore paid special attention in this section. To accomplish both purposes, I draw on extensive empirical research on sanctuary occurrences in Canada from 1983 to early 2009.

\section{Previous Sanctuary Research}

Contemporary sanctuary activities were manifest in the United Kingdom as early as the late 1970s. ${ }^{3}$ Through the 1980s, 1990s, and 2000s mass media reported sanctuary activity across Western Europe, including in France, Germany, Belgium, the Netherlands, Norway, Switzerland, and Finland, events that have yielded surprisingly little scholarship (but see this issue). In contrast, following its ascendancy beginning in the early 1980s in the US, sanctuary received extensive study. ${ }^{4}$ Yet, despite the large corpus of US work stemming from several disciplines, much remains unknown about aspects of this phenomenon, including how and why sanctuary in a specific form mutates or withers over time. In Canada, prior to the early 2000s, scholarship on sanctuary was limited to several brief, obscure articles. ${ }^{5}$ The only two extended accounts of singular Canadian sanctuary occurrences in the early 1990s were authored by religious authorities. ${ }^{6}$ Due in part to this dearth of research, in late 2005 a comprehensive study of sanctuary incidents was published. ${ }^{7}$ Overall, sanctuary activity was found to consist mostly of local efforts separated socially and geographically from one another, ${ }^{8}$ rather than a discernible and integrated religious movement spanning regions or the nation.

This 2005 study and other previous scholarship distinguish between sanctuary as "exposure" and as "concealment." 9 Exposure entails purposively gaining attention of mass media, the public, and political authorities at local, regional, and/or national levels; concealment is essentially about avoiding such attention. Sanctuary as exposure is the main focus here; the full extent and features of instances of concealed sanctuary-though worthy of study-remain unknown, a point to which I return in the conclusion. ${ }^{10}$ That said, in Canada the basic distinction has proven permeable. The 2005 study showed that incidents in Montreal, Toronto, Edmonton, and other Canadian cities entailed concealing practices within exposure strategies. Nonetheless, for this article's purposes a "sanctuary incident" is defined as an occurrence involving at least one migrant entering physical protection for at least one day to avoid deportation coupled with a strategic effort to concurrently expose this fact to mass media, broader publics, and political authorities. This definition throws into relief the kinds of practices not considered to be "sanctuary incidents" here. Occasionally publicized promises to grant sanctuary by church officials have not been followed by action, ${ }^{11}$ in which case migrants have avoided having to enter the physical protection of sanctuary but nonetheless have achieved a governmental reprieve or received legal status seemingly as a consequence. As well, since 1983 two instances of concealed sanctuary have been "exposed" after the fact, which is to say that exposure was not a strategy to aid those threatened with expulsion at the moment or in the immediate aftermath of granting sanctuary. ${ }^{12}$ Several churches have also assisted migrants to fight deportation using tactics closely associated with sanctuary efforts, for example, protesting, publicly proclaiming support, or paying legal fees, ${ }^{13}$ but without providing physical protection from authorities. These three sets of circumstances-threatened sanctuary, concealed sanctuary lacking purposeful exposure, and anti-deportation efforts of churches not entailing physical protection-are presently either unknowable or comparatively rare and are therefore excluded from consideration as incidents in this article.

\section{Research Procedures}

Research procedures necessarily overlap with those in the 2005 study. No organization or group collects and publishes comprehensive information about sanctuary incidents as defined above. Therefore, Internet search engines covering news and refugee-advocacy-related websites and indexes covering major newspapers and national popular and church periodicals from the mid-1970s to early 2009 were exhaustively searched. Providing the most comprehensive, up-to-date portrait of sanctuary possible therefore required sifting through a large volume of material to discern texts documenting sanctuary events. Beginning in the late 1990s, temporary websites had been erected that exposed migrants' predicament and instructed virtual visitors on how to support the sanctuary effort. These served as a further abundant data source. As well, forty-eight openfocused interviews with supporters intimately involved in sanctuary efforts were conducted from 2001 to 2007 . These persons included clergy, retirees, small business owners, labour union officials, lawyers, and medical professionals who were members of churches or local communities in which the incidents occurred. ${ }^{14}$ These interviews entailed questions on incidents' origins, organization, and outcomes; provided detail unavailable elsewhere; and facilitated access

(C) Randy K. Lippert, 2009. This open-access work is licensed under a Creative Commons Attribution-NonCommercial 4.0 International License, which permits use, reproduction and distribution in any medium for non-commercial purposes, provided the original author(s) are credited and the original publication in Refuge: Canada's Journal on Refugees is cited. 
to unpublished documents assembled by sanctuary providers from twelve incidents, including four of longer duration. Providers' documents included correspondence, leaflets, press releases, chronologies, petitions, texts of relevant legal decisions, and minutes of support group meeting. For this article, new data pertaining to incidents occurring from 2004 to April 30, 2009, were integrated and compared with existing data from 1983 to 2003.

\section{Part One: A Brief Portrait of Twenty-Six Years of Sanctuary in Canada}

In what follows I briefly update several basic features of sanctuary in Canada documented in the 2005 study: religious denomination, church location, recipients' characteristics (i.e., age, sex, number, and nationality), legal outcome, duration, and prevalence (i.e., year of commencement). I also identify key trends regarding several of these aspects since 2003.

\section{Religious Denominations and Church Locations}

To date, sanctuary has involved Christian denominations almost exclusively. Of the fifty incidents, eight (13 per cent) involved Anglican churches, twelve (24 per cent) United, fourteen (30 per cent) Catholic, and fifteen ( 30 per cent) involved other Christian denominations. This was expected given these three denominations' dominance, and that of Christian churches generally, within Canadian communities. The remaining sanctuary incident involved a Sikh and a Hindu temple. ${ }^{15}$ Several cities have experienced a disproportionate number of sanctuary incidents, including ten in Montreal (20 per cent), nine in Vancouver (18 per cent), five in each of Winnipeg (10 per cent) and Ottawa (10 per cent), and three in each of Calgary (6 per cent) and Toronto (6 per cent). Not surprisingly, these are cities where refugee determination hearings take place, ${ }^{16}$ where refugee claims are consistently rejected, and therefore where persons most likely to be later granted sanctuary reside. The remaining fifteen incidents have occurred in smaller centres across Canada (no incidents have occurred in Saskatchewan, Prince Edward Island, or northern jurisdictions).

\section{Recipients}

A total of 288 migrants now have been granted sanctuary across fifty incidents. The overall average age of adult migrants at the centre of incidents and for which information is available is $37.1(\mathrm{~N}=61)$. This means migrants' age has increased markedly, from $34.7(\mathrm{~N}=47)$ before 2003, to $45.1(\mathrm{~N}=14)$ afterward. This is tantamount to a shift from young adult to middle-aged adult migrants receiving sanctuary. In terms of sex, twenty-five incidents (50 per cent) involved migrants of both sexes, eighteen (36 per cent) involved males only, and seven (14 per cent) females only. Almost half the incidents (twenty-three) involved only one migrant. The remaining incidents involved two ( 6 per cent), three ( 6 per cent), four ( 6 per cent), five (10 per cent), and greater than five (14 per cent) migrants. Together these findings reveal, as noted in the 2005 study, that the most typical incident involves a single adult male. This is evinced in seventeen incidents ( 34 per cent). Significantly, almost half this total (eight, or 16 per cent of all incidents) has occurred since 2003, and although there remains some variability across the occurrences, this kind of incident has become decidedly more typical. Thus, while variability in the sex and number of sanctuary recipients continues, it has declined since 2003. Extreme variability remains evident, however, in the nationality of those granted sanctuary, whereby thirty-two nationalities are represented in the fifty incidents, with Salvadoran (four) being the most prevalent. This statistic remains consistent with the 2005 study and thus with the localized, contingent character of sanctuary provision in Canada. It remains largely incongruous with conceiving sanctuary as an organized social movement reacting to failed refugee claimants from specific regions or nations.

\section{Legal Outcomes and Duration}

In all fifty incidents, arrest ${ }^{17}$ and deportation of the migrants concerned was effectively delayed for at least several days. This time permitted church, community, and political support to grow through carefully managed public exposure of migrants' plight; funds to be raised through donations and other activities to retain superior legal representation and pay for private sponsorship applications, "humanitarian and compassionate" claims, and additional Federal Court appeals; and often some level of negotiation with immigration authorities and the Minister to commence. As well, as shown in Table 1, a majority of the fifty sanctuary incidents manifesting in Canadian communities over the past twentysix years have yielded favourable legal outcomes for migrants, eventually leading to immigrant status or comparable legal arrangements (e.g., a long-term permit to remain in Canada). Excluding the five incidents involving mixed, undecided, and unknown outcomes, 73.3 per cent (thirty-three of fortyfive) yielded legal status for the migrants involved.

\begin{tabular}{|c|c|c|}
\hline \multicolumn{3}{|c|}{$\begin{array}{l}\text { TABLE 1: Legal status outcome of migrants } \\
\text { granted sanctuary, 1983-(Apr. 30) } 2009\end{array}$} \\
\hline Outcome & $\mathrm{N}$ & $\%$ \\
\hline $\begin{array}{l}\text { Permanent/long-term legal status } \\
\text { expected/gained }\end{array}$ & 33 & 66.0 \\
\hline Deported/went underground & 12 & 24.0 \\
\hline Undecided/unknown & 4 & 8.0 \\
\hline \multirow[t]{2}{*}{ Some gained status/some deported } & 1 & 2.0 \\
\hline & 50 & 100.0 \\
\hline
\end{tabular}


The thorny path to securing permanent legal status or longterm permission to remain in Canada varied significantly across the incidents too. In almost one-third of the incidents sanctuary recipients were required to temporarily and "voluntarily" exit sanctuary (and Canada), legally enter nations such as the US and then reapply for immigrant status there, or re-enter the refugee determination process after a designated period consistent with Canada's immigration regulations at the time. In these instances this was accomplished usually through Department of Immigration's promises of special or expedited consideration of applications. Such promises remained unofficial and verbal to allow immigration and relevant political authorities to avoid declaring a general amnesty or establishing precedent affecting other migrants in similar dire situations. Other sanctuary cases ended with the granting of a Minister's Permit or a Federal Court ruling. The remaining incidents have concluded with migrants exiting to "go underground" and live "illegally"; surrendering to immigration officials; undergoing police arrest and deportation; or several of these outcomes.

\section{Recent Trends}

There is an overall average of two incidents commencing per year $(\mathrm{N}=50)$. Yet, suggestive of sanctuary's decline as a resistance strategy, as of April 30, 2009, no new incidents have appeared for twenty-two months (the Singh incident involving a Sikh and a Hindu temple began on July 1, 2007) and none commencing in Christian churches for more than two years. More significant is the recent trend in incident duration. The average duration of all ${ }^{18}$ sanctuary incidents is 314.6 days $(\mathrm{N}=49)$. However, in the $1980 \mathrm{~s}(\mathrm{~N}=2)$ it was only 19 days. During $1990-1994(\mathrm{~N}=5)^{19}$ the duration was 113.5 days. For $1995-1999(\mathrm{~N}=16)$ it reached 182.3 days; for 2000-2004, ( $\mathrm{N}=14), 313.6$ days; and for 2005-early 2009, $(\mathrm{N}=11)$, the average duration was an astonishing 686.6 days. This last statistic is remarkable because it is more than double the average incident duration in the preceding fiveyear period and almost four times the average duration of the late 1990s. In short, incident duration has increased dramatically since 2005 . This means a decidedly more arduous two-year sanctuary experience for providers entailing provision of continuous material and moral support, and for migrants entailing efforts to garner support and survive in the spatial confines of a church building for a protracted period. At the same time, only five of eleven incidents (46 per cent) since January 1, 2005, have yielded legal status for the migrants involved. This is markedly lower than the overall success rate of 70 per cent $(\mathrm{N}=30)$, noted in the 2005 study for the period ending 2003.

\section{Part Two: Considering Trends, the Merit-based Appeal, and Sanctuary's Future}

What follows is not the last word but rather an effort to further stimulate thinking about how and why sanctuary activity may be changing and to contemplate its future in Canada. One aspect that should be noted at the outset in this regard is that the recent trends, described above, are likely intertwined. That is, the lack of new incidents of late may well be due in part to would-be providers and recipients recognizing increasing duration and to a lesser extent fewer successes of other recent incidents. It may well be that potential and previous providers (and migrants) recognize the daunting sacrifices required over a much longer period to maintain sanctuary and the greater uncertainty about whether sanctuary would lead to legal status. As well, duration may be a direct reflection of greater difficulty in negotiating and otherwise securing legal status for the migrants involved that is reflected in the lower success rate. Nevertheless, the increased duration and the dearth of new incidents are also possibly due to other factors. These include less attention from mass media as well as the federal government's adoption of a tougher stance toward sanctuary recipients. Both would render sanctuary as "exposure" less feasible and more difficult to undertake. I discuss these two factors before turning to the merit-based appeal.

Sanctuary as "exposure" and its success are highly dependent on whether and how the incident is depicted in mass media. Sanctuary decisions elicit an exceptional quality. ${ }^{20}$ Stemming from this exceptional aspect, sanctuary has garnered mass media attention since 1983. This process placed migrants' experiences in the refugee determination process (including inadequate legal representation, translation errors, and general neglect of new evidence in support of claims) in the public spotlight along with claims about the ignored worth of migrant families and individuals to the nation-and, typically, to a specific local church and community. However, the dwindling rarity of sanctuary (the fact that there now have been fifty incidents) may well be making this form less extraordinary and newsworthy over the past few years. ${ }^{21}$ With each new occurrence, subsequent exposure and potential support may decline. It may also be more difficult to generate compassion and sympathy in mass media and/or among would-be supporters and providers from the local church and community due to the trend noted above toward not only more single adult male migrants entering sanctuary, but also toward older (middle-aged) male migrants compared, for example, to nuclear families with children. A sanctuary provider in Edmonton noted this was a factor in the support generated for a migrant family: 
If it was just him ... 'Okay you're a big boy ... look after yourself' ... but when you see little children and a woman that through no fault of her own ... [is] in a foreign country with no way of getting back, no way of communicating ... The congregation ... had a great deal of empathy for them which they may not have had for just $\mathrm{M}$ had he been single. (Interview 14, 2001)

Another factor leading to a lower success rate may well be a harder line among Ministers of Immigration and officials. While it remains unclear whether the arrest of Mohammed Cherfi in a Quebec City church in 2004 by police on a bailrelated rather than an immigration offence was encouraged by the Immigration Minister or officials, ${ }^{22}$ the extensive mass media coverage that followed undoubtedly suggested that a harder line in the form of physical arrest and detention of sanctuary recipients by immigration officials was now a real possibility. This harder line is also seen in the Immigration Minister's and officials' public refusals to negotiate with sanctuary recipients and supporters. This is especially evident in statements by Ministers of Immigration since the departure of Judy Sgro in 2004 and the Liberal government's subsequent failure to secure a majority of seats in Parliament in the following election, but especially since the subsequent rise to power of the Conservative party in 2006 and its more authoritarian approach to immigration and refugee policy. Emblematic of their new approach is the recent decision to grant more power over immigrant selection to the Minister of Immigration, an historical change from past immigration policy. ${ }^{23}$

Whatever the effect of these factors on sanctuary practices, as significant may be a gradual mutation in sanctuary discourse, one which may also shed light on sanctuary's future. While its absence from the formal refugee determination process continues, even after enabling legislation, the merit-based legal appeal has been gradually more present in sanctuary discourse. It is this less obvious discursive mutation to which I now turn.

\section{Refugee Determination and the Merit-based Appeal}

The twists and turns of ever-mutating Canadian refugee determination and related deportation policies and practices are too complex to recount here. ${ }^{24}$ Nevertheless, some background is required. Refugee determination adopted in the 1980s what has been termed an "advanced liberal" character evident in the movement of responsibility away from the whims of federal political authorities and Department of Immigration officials and into the hands of an arms-length Immigration and Refugee Board (IRB). Cohering with this shift toward governing refugee determination "at a distance" was the march of administrative law into determination-as seen in establishment of the oral hearings held before this tribunal-that effectively created a legal domain never seen before. Put another way, the inherently political question of "who is a refugee?" underwent juridification in Canada. As well, knowledge generated for refugee determination purposes had been deemed politically tainted since formalization of the process in the early 1980s and for this reason in 1989 the documentation centre was implemented to overcome this situation, its openness to public scrutiny being a key element of the new program's design. ${ }^{25}$ It is this ongoing effort to ensure distance between determination decisions and the whims of Canadian political authorities that serves as a condition of possibility for the later ascendancy of the merit-based appeal.

Absent in determination policy from the 1970s onward, and still omitted from formal determination practices, is a merit-based appeal of a rejected refugee claim that would allow, for example, introduction of new evidence supportive of a claim during a formal hearing in the event of a negative status decision. Nonetheless, three "appeals" 26 have become available during the determination domain's formative period. The first is an appeal at the Federal Court of Canada on points of law if an error is deemed to have occurred. The second is a risk assessment for failed refugee claimants facing deportation whereby a Department of Immigration official examines a failed claimant's file to determine if an immediate threat to the claimant's life will result from deportation. If a risk of return and Federal Court review are rejected, a claimant can request humanitarian and compassionate intervention by the Minister of Immigration to stay. The vast majority of all three "appeals" by refugee claimants, however, tend to be rejected.

Two other developments require brief mention for the discussion that follows. First, during this formative period the formal introduction of private sponsor resettlement programs-many of which were church affiliated-also occurred. ${ }^{27}$ Resettlement from then on would have a decidedly more private character. Second, another heretofore unrecognized aspect of this general shift consistent with the onset of advanced liberalism ${ }^{28}$ occurring in the 1990 s was the drastic reduction in Ontario and other provincial jurisdictions of public funding for legal aid provision. Thus, it became more difficult for refugee claimants to secure adequate publicly funded legal representation for determination hearings, requiring them to rely on private sources for adequate representation more than previously. It is from this context that sanctuary emerged, the factors encouraging its emergence therefore including a movement of responsibility for adequate determination and resettlement toward private spheres. 


\section{The Rise of the Merit-based Appeal in Sanctuary} Discourse

What goes unrecognized in recent public and mass media discourse is that calls from refugee advocates for introduction of a merit-based appeal ${ }^{29}$ have been around for at least a quarter of a century in Canada whereas a clear link between this call and sanctuary activity is evident only later in 1993 in relation to one incident involving the Southern Ontario Sanctuary Coalition (SOSC). As a Coalition member stated: "We didn't take on more cases ... while we were carrying on the struggle with the government over our demand for a fair appeal system, which was the focus of our demands, our actions, the legal focus" (Interview 4, 2001). A Coalition member further remarked:

The government was restricting appeals and the legislation from [19]89 decisively restricted it. Not absolutely, but almost absolutely. You can't get an appeal on the merits of the case, only on the procedure. If the judge really fell asleep during the trial, you'd get an appeal. (Interview 3, 2001)

Yet, the Coalition's focus on the appeal was anomalous among sanctuary efforts and not taken up by other sanctuary providers across Canada until long after 1993. What is significant, however, in contemplating the future of sanctuary in its "exposure" form is that this Coalition was not involved in granting this form of sanctuary to additional migrants after 1993. Thus, SOSC's advocacy for the meritbased appeal as a bona fide alternative to sanctuary and recognizing the two on the same plane seems to cohere with their avoidance of instigating this form of sanctuary in their later efforts.

The call for the appeal stemmed mostly from elsewhere and, in particular, those well-versed in determination practices:

There were a lot of groups-including the CCR - [the Canadian Council for Refugees which raised the issue of] just the lack of meaningful appeal, that there could be new information that was directly relevant [to the claimant's case], and there was no place for it to go. And I think what happened in 93 [when the Sanctuary Coalition granted sanctuary to twenty-three claimants] ... was just maybe the tip of a very large iceberg that we had surfaced. And it was like there had to be a way of appealing or more of this [sanctuary] was going to happen ... and it didn't come from the government, it came from the refugee board people [i.e., IRB members]. Like they knew that there were times when a document would arrive, after [the case had been rejected], that was directly relevant. (Interview 5, 2001; emphasis added)
After a few sanctuary incidents had occurred across Canada in preceding years, in 1994 the now defunct Interchurch Committee on Refugees (ICCR) comprising representatives from Canada's mainline churches launched a pilot project called "Keeping Faith." 30 Housing migrants in churches plainly came with challenges and risks and this proposal was an explicit attempt to create a more organized, less risky version of sanctuary (that was not unlike the SOSC's effort, in that no one would know migrants' locations while in sanctuary). A provider noted in 2001:

I think we were getting discouraged that certain cases were falling through the cracks that we felt were strong cases and they were not being accepted. And of course we don't have an appeal, so what can you do? So what we thought was ..., maybe this would be a way of getting groups of churches across the country to participate and what we proposed was that, for instance, if we found a refugee or a refugee family that we felt had a strong legitimate case thatfor whatever reason-had failed all the layers of hearings ... like what we had discovered is a number of them actually who were quote, unquote, going underground anyway and so we thought what about if we made this project where ... they would go underground but there would be a contact person who knew them [and] who would be our contact? (Interview 2, 2001; emphasis added)

Significantly, while referred to in this 2001 interview excerpt, texts associated with this "Keeping Faith" initiative from 1994 avoid mention of a merit-based appeal as an aim. Its emphasis came later and was not a key justification at the time.

That the expressed need for a merit-based appeal in refugee policy did not stem from local sanctuary providers is further evinced by the fact that interviews from 2001 and 2002 reveal providers rarely refer to an "appeal." When they do, "appeal" tends to be used loosely to refer to one or more of the three means of gaining permission to remain in Canada described earlier in relation to the specific migrant(s) to whom sanctuary was granted, rather than a formal and extensive legal procedure conducted before a specialized judicial board. For example, a provider acknowledged "various means of appeal" (Interview 17, 2001); another noted "a number of different other appeals I guess that they go through" (Interview 2, 2001). Yet another remarked:

They went to a lawyer I recommended and their case is now going ... into the humanitarian appeals [sic]. So, generally you will, if you get the right lawyer and the right stage of appeal, if all being well, usually you can work it through ... (Interview 13, 2001) 
Early on, then, the merit-based appeal was promoted by refugee advocates in the legal know, not by local sanctuary providers, most of whom were non-experts drawn from the local church and community and unfamiliar with existing refugee policy, especially in the early going of their sanctuary provision effort. ${ }^{31}$ It is after 2002 that the need for a meritbased appeal became a central claim of sanctuary providers, a nascent "Holy Grail," as it were. This was undoubtedly sparked at least in part by the appeal's appearance in new immigration and refugee legislation the year prior.

Following a comprehensive review of Canada's immigration and refugee policy the Immigration and Refugee Protection Act (IRPA) was passed in 2001 and came into force in June 2002. This Act set out provisions for a Refugee Appeal Division (RAD) that would for the first time consider appeals of rejected cases based on the merits of the refugee claim. ${ }^{32}$ Beginning in 1989 two IRB officials had become responsible for deciding whether a claim for refugee status met criteria outlined in the international Refugee Convention. Under IRPA, refugee claimants would now appear before only one IRB official. It was acknowledged, however, that there was a potential risk of arbitrary and erroneous decision-making under this new arrangement due to a single board member making decisions that could profoundly affect a claimant's future, a concern fed by several public scandals that occurred since 1989 centring on bribery of appointed IRB members and their biased decision making. This shift from two board members to one was central to the RAD's justification and placing the appeal in draft legislation was a key political maneuver to overcome refugee advocate resistance (but not necessarily to overcome sanctuary per se-providers were not invited to participate in the formal legislative review as sanctuary providers, unlike what was to transpire beginning in 2004, as described below). On the eve of the new legislation's promised implementation a key member of SOSC, who is also a refugee advocate, noted that "the new legislation does allow for an appeal at the refugee board and that's a major step forward. It's in writing, it's not in person, but it's still a big step" (Interview 5, 2001). This sentiment was to be short-lived. Implementation of RAD never happened. From then on the appeal's absence became increasingly publicly touted as an alternative to sanctuary as "exposure."

In June 2004, then-Immigration Minister Judy Sgro made an unusual public call for mainline Christian churches to stop granting sanctuary, claiming churches were serving as a "back door" for failed refugee claimants seeking legal status in Canada. Church representatives were then invited to meet with the Immigration Minister and her staff. In September 2004, a meeting with representatives from Roman Catholic, Presbyterian, Lutheran, Mennonite, Quaker, and
United denominations was held. The Minister made an offer to churches that would permit their regular submission of names of exceptional cases for independent review with a ten-day turnaround. ${ }^{33}$ The Minister argued the other "appeals" protected failed claimants at risk. She nonetheless proposed to church representatives they could submit about twelve cases to the Minister to review annually, ${ }^{34}$ not unlike existing practices entailing recommendations made within the private sponsor resettlement programs noted earlier. This is significant because it assumed a small number of exceptions would be required and it would be the Minister who would ultimately decide their exceptional status. This new arrangement would displace the stated need for sanctuary and the merit-based appeal system (the assumed cost of which was deemed to contrast sharply with existing "advanced liberal" demands for efficiency) enshrined in the new Act. Yet, it is difficult for sanctuary to be incorporated into existing refugee determination (and selection) processes due in part to differences between "the values of the agencies of civil society and norms of public accountability." 35 The issue it raises is analogous to the conflict-ridden plan of the former US Bush administration to publicly fund faith-based groups to dispense services to the poor. For their part, church leaders argued publicly there would be fewer sanctuary incidents if IRPA's RAD had been implemented. When details of this offer became public, due to its secret and exclusive nature, a rash of criticism ensued. In early November 2004, the Minister responded with a revised arrangement that would give other (secular) civil society groups formal authority to bring a few cases forward annually. A meeting with church representatives followed in midNovember. Yet, church representatives subsequently refused to become part of this process. One church representative from the United Church, the denomination involved in the second-greatest number of incidents (i.e., twelve), stated that sanctuary would continue with or without approval of this new process. ${ }^{36}$

Nevertheless, since 2004 the explicit link between the two mechanisms has been increasing. By September 2004, a regional Interfaith Sanctuary Coalition had formed and was already claiming the need to implement the appeal. In 2006 the first Presbyterian Church statement on sanctuary was published and made a similar recommendation. ${ }^{37}$ As a Catholic bishop remarked at a 2007 rally: "The problem is not recourse to sanctuary, but the flawed Canadian refugee determination system that leaves too many refugees without protection." 38 As with so much refugee politics, international bodies also provided a source of domestic articulation of the issue as seen when an Inter-American Commission on Human Rights report from the late 1990s that assessed Canada's treatment of asylum seekers in 
Canada's refugee determination system was invoked during this period. The Commission recommended an appeal process on the merits of a claim for refugee status. In the fall of 2004, KAIROS, an ecumenical group, launched a public campaign calling for implementation of the RAD. More than twenty-five thousand persons signed petitions submitted to Parliament in April and June of 2005. More recently, a May 2007 report by the House of Commons Standing Committee on Citizenship and Immigration recommended that officials respect the right of churches and other religious organizations to provide sanctuary to those believed to need protection. This had followed an invitation in 2006 to not only church representatives, but also local sanctuary providers, to represent their thoughts on sanctuary to parliamentarians at Committee hearings. Front and centre in their testimony to the Committee was the link between the absence of the appeal and the granting of sanctuary. One noted: "Canada is obligated to provide sanctuary to those in need, and there are times like the present, given the lack of appeal, when as citizens and human beings we have a fundamental and moral obligation to provide sanctuary within Canada." ${ }^{39}$ The SOSC held their first national consultation in November 2007 (see this issue), bringing together sanctuary providers from beyond the local Ontario region to discuss sanctuary experiences and strategy. Though there have been meetings amongst sanctuary providers from different regions before, this was the first of national scope. The outcome included a call to implement the merit-based appeal. It is intriguing that no new sanctuary as "exposure" incidents ${ }^{40}$ have occurred since this consultation was held. Through a growing embrace of the merit-based appeal, the aim of sanctuary providers is becoming less parochial and local, and more national and policy-oriented.

Another way that sanctuary is changing consonant with the foregoing requires mention. The 2005 study argued that sanctuary has a complex relationship with law. Sanctuary discourse was shown to comprise at least three legal narratives, including a "with the law" narrative, ${ }^{41}$ in which law is assumed to be neither majestic nor oppressive (the other two narratives), but rather as a strategy to pursue personal interests in a pragmatic game. This connection is seen in the following typical excerpt from interviews with sanctuary providers in which an "appeal" is seen to be necessarily carried out by lawyers:

So anyway they came home and that was the point at which they believed that they were going to be deported. And again, the attorney said, well listen, we are filing one more appeal and filing an appeal to stay the deportation, I am filing an appeal to have the original decision by immigration reviewed. I am filing all of these appeals. (Interview 36, 2001; emphasis added)
The appeal is evinced as tightly tethered to the purchase of lawyers' services: "And then it was only when we decided okay let's try to fight this, let's try to file an appeal to the Division of Immigration. It was only then that we decided to consult a lawyer" (Interview 7, 2001). These are pragmatic concerns and therefore one consequence of accepting the realization of the merit-based appeal as one of sanctuary's central goals is to begin to limit horizons to legal games, to the "with the law" legal narrative to the neglect of other narratives that have helped render sanctuary possible. To the extent this occurs, sanctuary activity is likely to continue to dwindle in the Canadian context, ${ }^{42}$ the signs of which are found in the trends identified above.

\section{Conclusion}

The foregoing allows some conclusions to be drawn about sanctuary activity in Canada. It remains almost exclusively a Christian phenomenon occurring in major urban centres in which refugee determination processes take place. Key trends that are likely interrelated are the increasing duration of incidents, the decreasing success, and the lack of new incidents. While probably not the end of sanctuary in its "exposure" form (there will likely be isolated future incidents), these are nonetheless signs of its decline as an effective strategy of securing legal status for migrants facing imminent deportation. It is possible the same factors leading to its decline have been fuelling an increase in sanctuary as "concealment" in recent years, but this remains difficultby definition-to know and, barring research involving key informants, might only become known long after the fact.

While factors such as "compassion fatigue" and less interest among the public and mass media, coupled with a harder federal government line, may be related to these trends, the claims and discourse of sanctuary providers operating outside these dominant institutions matters too. While not implemented, and therefore present only in discourse, the merit-based appeal is real in its enabling effects. This is evinced in the way it has been binding local sanctuary providers together in common pragmatic cause. The appeal may yet turn out to be a means to seamlessly merge concerns of sanctuary providers, refugee advocates, and immigration authorities. If those who would grant sanctuary are effective in generating greater support for implementation of the merit-based appeal they will have made a significant difference. This also means that sanctuary's effects, as noted in the 2005 study, ${ }^{43}$ will have reached well beyond the lives of migrants who find themselves at the centre of incidents.

A final note about sanctuary research is in order. While most Western countries have experienced sanctuary activity in recent decades, it has taken dissimilar trajectories and adopted varied forms. The sanctuary movement in the

(C) Randy K. Lippert, 2009. This open-access work is licensed under a Creative Commons Attribution-NonCommercial 4.0 International License, which permits use, reproduction and distribution in any medium for non-commercial purposes, provided the original author(s) are credited and the original publication in Refuge: Canada's Journal on Refugees is cited. 
US effectively expired in the early 1990s but recently several cities in California have announced they will serve as public sanctuaries, thus suggesting resurgence (see also this issue). The reasons for changes in sanctuary activity and its manifestations such as this would benefit from more systematic comparative research between countries, especially since each is oriented to specific federal policy regimes with little or no international co-operation currently evident (though Canadians played a key role in the US Sanctuary Movement ${ }^{44}$ ). Mirroring the Canadian context, sanctuary in Germany also commenced in 1983, has been similarly organized as incidents, and has shown a remarkably similar overall rate of success. ${ }^{45}$ Rather than looking to the US for insight into sanctuary, due to more analogous characteristics and likely available data, comparison of sanctuary in Canada with Germany could permit making further sense of mutations in sanctuary activity evident in the Canadian trends above as well as beyond the Canadian context.

\section{Notes}

1. Sanctuary as "exposure" has all but ceased in some European countries due to the brute force of the state in the form of the "storming" of sanctuaries. This is especially evident in the UK and France. To Paul Weller's early question about sanctuary's prospects in the UK subtitled "Beginning of a Movement?" time has answered "no." See Paul Weller, Sanctuary: The Beginning of a Movement? (London: Runnymede Trust, 1987).

2. Randy Lippert, Sanctuary, Sovereignty, Sacrifice: Canadian Sanctuary Incidents, Power, and Law (Vancouver: University of British Columbia Press, 2006).

3. Paul Weller, "Sanctuary as Concealment and Exposure: The Practices of Sanctuary in Britain as Part of the Struggle for Refugee Rights" (paper presented at conference "The Refugee Crisis: British and Canadian Responses," Keble College and Rhodes House, Oxford, England, 4-7 January 1989).

4. For example, Gregory Wiltfang and John Cochran, "The Sanctuary Movement and the Smuggling of Undocumented Central Americans into the United States: Crime, Deviance, or Defiance?" Sociological Spectrum 14 (1994): 101-28; Gregory Wiltfang and Doug McAdam, "The Costs and Risks of Social Activism: A Study of Sanctuary Movement Activism," Social Forces 69 (1991): 987-1010; David Kowalewski, "The Historical Structuring of a Dissident Movement," Research in Social Movements, Conflict and Change 12 (1990): 89-110; Jeffrey Nelson and Mary Ann Flannery, "The Sanctuary Movement: A Study in Religious Confrontation," Southern Communication Journal 55 (1990): 372-87; Martha Gibson, "Public Goods, Alienation, and Political Protest: The Sanctuary Movement as a Test of the Public Goods Model of Collective Rebellious Behavior,"
Political Psychology 12 (1991): 623-51; Robin Lorentzen, Women in the Sanctuary Movement (Philadelphia: Temple University Press, 1991); Miriam Davidson, Convictions of the Heart: Jim Corbett and the Sanctuary Movement (Tucson: University of Arizona Press, 1988); Colleen Greer, "Ideology as Response: Cultural and Political Process in the Sanctuary Movement," Social Thought and Research 20 (1997): 109-28; Anne Hildreth, "The Importance of Purposes in 'Purposive Groups': Incentives and Participation in the Sanctuary Movement," American Journal of Political Science 38 (1994): 447-63; Susan Coutin, The Culture of Protest: Religious Activism and the U.S. Sanctuary Movement (Boulder: Westview Press, 1993); Susan Coutin, "Enacting Law through Social Practice," in Contested States: Law, Hegemony and Resistance, ed. Mindie Lazarus-Black and Susan Hirsch (New York: Routledge, 1994), 282-303; Susan Coutin, "Smugglers or Samaritans in Tuscon, Arizona: Producing and Contesting Legal Truth," American Ethnologist 22 (1995): 549-71; Susan Coutin and Susan Hirsch, "Naming Resistance: Ethnographers, Dissidents, and States," Anthropological Quarterly 71 (1998): 1-17; Hilary Cunningham, "Crossing Boundaries in a Gated Globe: Transnational Politics at the Edges of Sovereignty," Global Networks 1 (2001): 369-87; Hilary Cunningham, "The Ethnology of Transnational Social Activism: Understanding the Global as Local Practice," American Ethnologist 26 (2000): 583-604; Hilary Cunningham, God and Caesar at the Rio Grande (Minneapolis: University of Minnesota Press, 1995); Hilary Cunningham, "Sanctuary and Sovereignty: Church and State along the U.S.-Mexico Border," Journal of Church and State 40 (1998): 371-87; Hilary Cunningham, "Transnational Social Movements and Sovereignties in Transition: Charting New Interfaces of Power at the U.S.-Mexico Border," Anthropologica 44 (2002): 185-96; Kristin Park, "The Religious Construction of Sanctuary Provisions in Two Congregations," Sociological Spectrum 18 (1998): 393-421; Kristin Park, "The Sacrifice Theory of Value: Explaining Activism in Two Sanctuary Congregations," Sociological Viewpoints 12 (1996): 35-50.

5. David Matas, "Canadian Sanctuary," Refuge 18 (1988): 14-17; see also David Matas, The Sanctuary Trial (Winnipeg: Legal Research Institute of the University of Manitoba, 1989), 147-51; W. G. Plaut, Asylum: A Moral Dilemma (Westport, Conn.: Praeger, 1995), 129-37; Charles Stastny and Gabrielle Tyrnauer, "Sanctuary in Canada," in The International Refugee Crisis: British and Canadian Responses, ed. V. Robinson (London: Macmillan, 1993), 175-95.

6. Paul Reynolds, Faith Subdues Kingdoms: A Pastor's Challenge to Immigration (New Westminster, B.C.: Conexions Publishing, 1992); Mary Leddy, At the Border Called Hope: Where Refugees Are Neighbours (Toronto: Harper Collins, 1997).

7. Lippert, Sanctuary, Sovereignty, Sacrifice.

8. Ibid. 
9. Ibid.; Weller, "Sanctuary as Concealment and Exposure."

10. Lippert, Sanctuary, Sovereignty, Sacrifice.

11. Interview 31. See also Marian Scott, "Minister Offers Church Refuge for Ghanaians," Montreal Gazette, 26 March 1988, A3; Fred Serre, "Church Intervenes for Refugee," Canadian Baptist, July/August (1992): 47-8; Southern Ontario Sanctuary Coalition, "A Declaration: A Civil Initiative to Protect Refugees," press release, Toronto, 7 October 2002.

12. Michael Farber, "Saving Refugee Was Bold Act," Montreal Gazette, 22 January 1985, A3; Interview 47.

13. See "Refugees Desperate for Safe Haven Get Help from Churches" Ottawa Citizen, 7 December 1996, C7; Bob Bettson, "Suffering under New System," United Church Observer 55 (1992): 18.

14. Persons granted sanctuary were not formally interviewed due to university research ethics guidelines concerning vulnerable populations and due to language barriers. Regarding the former, these persons were in an exceedingly vulnerable situation due to being without legal status in relation to state authorities. There was a risk they would agree to an interview thinking it would improve their chances of achieving status through legal proceedings or humanitarian applications, and a risk that authorities might acquire interview data and later somehow identify these personsto their detriment-due to a unique element of the incident in which they were involved.

15. An Islamic religious leader threatened to enter the sanctuary of a mosque in Montreal when facing deportation recently. Yet, there is currently only very limited evidence that sanctuary actually occurred.

16. The continued presence of the SOSC and their tactics in Toronto that differ from other incidents are a partial explanation for the surprising under-representation in sanctuary.

17. Until 1998 neither Immigration officials nor police had entered a legitimate church to arrest those granted sanctuary on immigration charges or to charge their providers with an offence. In contrast to the Canadian context, in the "Viraj Mendis" incident in Britain, after a long period British authorities entered a church to arrest the migrant in question. See Weller, "Sanctuary as Concealment and Exposure." Similar actions have occurred in Germany and France in the 1990s. See Yojana Sharma, Religion-Germany: Church, State Clash over Sanctuary for Refugees. 1998, 11/26/00, <http:// www.oneworld.org/ips2/jul98/03_34_002.html>; Charles Trueheart and Anne Swardson, "Thousands Denounce Detention of Migrants," Ottawa Citizen, 24 August 1990, A6. The "sanctuary trials" resulted in prosecution of eight "U.S. Sanctuary Movement" members in the 1980s. See Matas, The Sanctuary Trial. Police entered a "church" lacking a city permit to arrest several Chileans in Montreal in 1998. In March 2004, Quebec City police entered a Catholic church to arrest and detain Mohammed Cherfi. See Donna Sinclair, "The Cherfi Arrest: Sanctuary Violated," United Church Observer, April (2004), online: <http://www.ucobserver.org/justice/2004/04/the_cherfi_arrest/>.
18. Other than the SOSC incident which occurred in 1993.

19. Other than the SOSC incident.

20. Lippert, Sanctuary, Sovereignty, Sacrifice.

21. It is possible, however, that if more time passes, a new sanctuary incident might again begin to appear "exceptional" and thus become capable of generating mass media attention.

22. Contrary to mass media coverage, it was not the first arrest of sanctuary recipients in Canada, See note 17.

23. Bruce Cheadle, "Conservatives Survive Confidence Vote," Globe and Mail, 9 June 2008, <http://www.theglobeandmail.com/servlet/story/RTGAM.20080609.wimmigration0609/BNStory/National>.

24. See Randy Lippert, "Canadian Refugee Determination and Advanced Liberal Government," Canadian Journal of Law and Society 13 (1998): 177-207.

25. See Randy Lippert, "Canadian Refugee Determination and Advanced Liberal Government."

26. I acknowledge that my use of "appeal" to refer to the humanitarian and compassionate and risk assessment procedures is controversial in this context since they do not involve reconsideration of matters addressed at refugee hearings.

27. See Randy Lippert, "Rationalities and Refugee Resettlement," Economy and Society 27 (1998): 380-406.

28. G. Park and Randy Lippert, "Legal Aid's Logics," Studies in Law, Politics, and Society 45 (2008): 177-201.

29. "No Secret Sanctuary," Ottawa Citizen, 16 November 2004.

30. ICCR, Keeping Faith: A Guide for Church Group Participation in the Pilot Project (Toronto: Inter-Church Committee for Refugees, 1994).

31. Lippert, Sanctuary, Sovereignty, Sacrifice.

32. The avoidance of a blanket amnesty in Canada has entailed deployment of all manner of temporary processes through the 1980s and 1990s to stave off full commitment, including the PDRCC, DROC, and the Administrative Review. See Lippert, "Canadian Refugee Determination and Advanced Liberal Government."

33. E. Thompson, "Churches Refuse to Play 'Immigration Department': Deal Would Have Given Religious Groups Right to Select Failed Refugee Claimants for Reconsideration by Minister," Ottawa Citizen, 3 November 2004.

34. Ibid.

35. M. Dean, Governing Societies (New York: Open University Press, 2007).

36. E. Thompson, "Churches Refuse to Play 'Immigration Department."

37. Presbyterian Church, Sanctuary: A Statement and Guidelines for Congregations. (Toronto: Presbyterian Church, 2006).

38. First Unitarian Congregation in Ottawa, "Second National Rally on Refuge Rights and Sanctuary," <http://www.uuottawa.com/sanctuary/rally.shtml> (accessed July 30, 2008).

39. Canada, Meetings with Standing Committee on Citizenship and Immigration, $39^{\text {th }}$ Parliament, $1^{\text {st }}$ Session, Standing 
Committee on Citizenship and Immigration, Evidence Contents. 2 November 2006.

40. Whether sanctuary as "concealment" or a new form more consistent with SOSC's past practices has increasingly occurred as a result of this consultation or otherwise is unknown.

41. Lippert, Sanctuary, Sovereignty, Sacrifice; see also Patricia Ewick and Susan Silbey, Common Place of Law: Stories from Everyday Life (Chicago: University of Chicago Press, 1998).

42. Future research may yet reveal a trend toward sanctuary themes being appropriated by secular groups in secular contexts. Such a theme can be seen in the experimental "Don't Ask, Don't Tell" campaign in Toronto, Canada whereby persons without legal status continue to receive social benefits from the (Toronto) municipal government without being identified, thus representing a unique configuration of "exposure" and "concealment" strategies and "before the law" and "with the law" narratives. I am indebted to an anonymous reviewer for this point.

43. See Lippert, Sanctuary, Sovereignty, Sacrifice.

44. Ibid.

45. Sanctuary (Berlin: German Ecumenical Committee on Church Asylum, 2007).

Randy Lippert is an associate professor of sociology and criminology in the Department of Sociology, Anthropology, and Criminology at the University of Windsor, Ontario. His research interests include immigration and refugee policies, surveillance practices and urban governance and security arrangements. He recently published the book, Sanctuary, Sovereignty, Sacrifice: Canadian Sanctuary Incidents, Power, and Law (Vancouver: University of British Columbia Press, 2006). 